\title{
Connecting With the Audience: Testing the Use of the Entertainment Education Strategy and Narrative in an SMS Intervention
}

Jessica Fitts Willoughby, PhD; Zhaomeng Niu, MA; Shuang Liu, MA

Edward R. Murrow College of Communication, Washington State University, Pullman, WA, United States

\section{Corresponding Author:}

Jessica Fitts Willoughby, PhD

Edward R. Murrow College of Communication

Washington State University

PO Box 642530

Pullman, WA, 99164-2530

United States

Phone: 15093357926

Fax: 15093353772

Email: jessica.willoughby@wsu.edu

\section{Abstract}

Background: Short message service (SMS) interventions can influence knowledge, attitudes, and behaviors related to health. While SMS for health promotion has grown in popularity, there is a paucity of research that examines specific characteristics of text message interventions to determine what may make them effective. Previous research in health communication has identified strategies that can effectively lead to positive health outcomes, such as the use of entertainment education (EE). EE is the practice of embedding educational content in an entertaining format. One component of EE is the use of narrative, which allows for audience members to identify with characters, reduce counter-arguing of a message, and engage with the information presented.

Objective: To determine the potential for the use of narratives and the entertainment education strategy in a text message intervention. In particular, we focused on a topic relevant on college campuses in the United States, alcohol and hookups, with young adult females.

Methods: In spring 2015, we conducted a 3X1 posttest only experiment with 137 college females. We developed two sets of text messages about alcohol and hookups based on formative research with the target audience. The first set used narrative to convey information about Sara (a fictitious student) and her experiences. The second set used no story to present the same information. Messages were pretested prior to the experiment, and participants identified the information presented to be similar with differences in format. A third set of messages served as a control, focusing on campus events. We recruited participants from a communication college participant pool. Participants signed up to come to the lab to complete the experiment. Participants were given a mini tablet on which to view the messages that included an iMessage conversation featuring the messages for their condition. After viewing the messages, participants clicked on a link that took them to a questionnaire.

Results: Transportation, which is whether the viewer felt engrossed in the story, differed by condition $\mathrm{F}(2,133)=6.368, P<.01$. Only the control condition differed significantly from the narrative condition, however, with those in the narrative condition experiencing greater transportation than those in the control condition. Counter-arguing differed by condition $\mathrm{F}(2$, 132) $=14.680$, $P<.001$, with greater counter-arguing in the narrative condition than the non-narrative $(P<.001)$. Identification did not differ by condition.

Conclusions: Transportation may occur via text message; however, counter-arguing worked in reverse of what would typically be hypothesized, and identification did not significantly differ by condition. The finding of transportation being greater for the narrative condition is promising, as it highlights that even through a series of six 160-character messages, young adult females who view narrative messages can feel somewhat more transported than participants who view messages about general campus events. However, it appears that narrative is difficult in such a small space, as identification did not occur, and identification is often important for people to feel connected to the characters, which can then influence attitudes and behaviors. Future work should examine other elements associated with narrative to assess potential effects. 
(iproc 2016;2(1):e43) doi: 10.2196/iproc.6113

\section{KEYWORDS}

short message service (SMS); text message; intervention; cell phone; entertainment education

This poster was presented at the Connected Health Symposium is displayed as an image in Figure 1 and as a PDF in Multimedia 2016, October 20-21, Boston, MA, United States. The poster Appendix 1.

Figure 1. Poster.

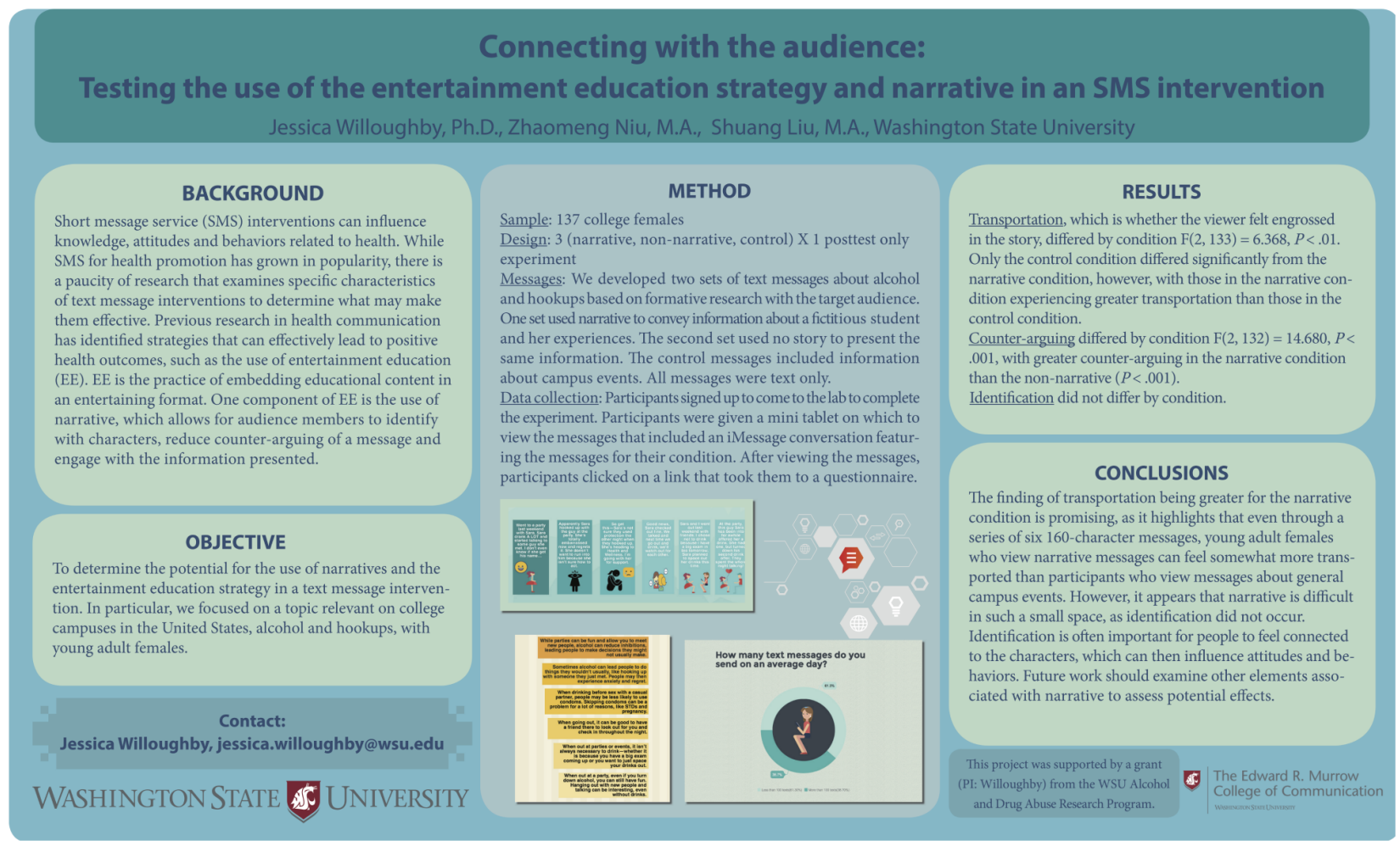

\section{Multimedia Appendix 1}

Poster.

[PDF File (Adobe PDF File), 793KB-Multimedia Appendix 1]

Edited by T Hale; submitted 04.06.16; peer-reviewed by CHS Scientific Program Committee; accepted 02.08.16; published 30.12.16

Please cite as:

Willoughby JF, Niи Z, Liu S

Connecting With the Audience: Testing the Use of the Entertainment Education Strategy and Narrative in an SMS Intervention iproc 2016;2(1):e43

URL: http://www.iproc.org/2016/1/e43/

doi: 10.2196/iproc.6113

$P M I D$ :

CJessica Fitts Willoughby, Zhaomeng Niu, Shuang Liu. Originally published in Iproceedings (http://www.iproc.org), 30.12.2016. This is an open-access article distributed under the terms of the Creative Commons Attribution License (http://creativecommons.org/licenses/by/2.0/), which permits unrestricted use, distribution, and reproduction in any medium, provided the original work, first published in Iproceedings, is properly cited. The complete bibliographic information, a link to the original publication on http://www.iproc.org/, as well as this copyright and license information must be included. 